\title{
PENGGUNAAN GRUP WHATSAPP SEBAGAI MEDIA PEMBELAJARAN TERHADAP PESERTA DIDIK DTA AT-TAWAKAL KOTA BANDUNG
}

\author{
Resa Iskandar \\ IKIP Siliwangi - Cimahi - Jawa Barat - Indonesia \\ resaiskandar09@gmail.com
}

Received: Januari, 2020; Accepted: Mei, 2020

\begin{abstract}
This study to describe the: 1) implementation of the use of WhatsApp groups as learning media for DTA At-Tawakal students in the city of Bandung, 2) the result of the use of WhatsApp groups as learning media for DTA At-Tawakal students in the city of Bandung, 3) evaluate of the use of WhatsApp groups as learning media for DTA At-Tawakal students in the city of Bandung. This research is a descriptive qualitative research. The subjects of this study were the DTA At-Tawakal tutors and students. Data collection is done by the method of observation,interviews, and documentation. The results of the study indicate that the implementation of this research was carried out throught the implementation and monitoring stages, the results of the implementation of the research into student in research are helped to obtain learning by using the WhatsApp groups as the medium, the evaluation of this research is to improve the existing deficiencies and obtacles.
\end{abstract}

Keywords: WhatsApp group WhatsApp, learning media.

\begin{abstract}
Abstrak
Penelitian ini bertujuan untuk mendeskripsikan: 1) Pelaksanaan penggunaan grup WhatsApp sebagai media pembelajaran terhadap peserta didik DTA At-Tawakal di Kota Bandung, 2) Hasil penggunaan grup WhatsApp sebagai media pembelajaran terhadap peserta didik DTA At-Tawakal di Kota Bandung, dan 3) Evaluasi penggunaan grup WhatsApp sebagai media pembelajaran terhadap peserta didik DTA At-Tawakal di Kota Bandung. Penelitian ini merupakan penelitian deskriptif kualitatif. Subyek penelitian ini adalah tutor dan peserta didik DTA At-Tawakal. Pengumpulan data dilakukan dengan metode observasi, wawancara dan dokumentasi. Hasil penelitian menunjukkan bahwa pelaksanaan penelitian ini dilakukan melalui tahap pelaksanaan dan monitoring, hasil dari pelaksanaan penelitian ini peserta didik menjadi terbantu untuk mendapatkan pembelajaran dengan penggunaan grup WhatsApp sebagai medianya, evaluasi dari penelitian ini adalah memperbaiki kekurangan dan hambatan yang ada. Kata Kunci: Grup WhatsApp, media pembelajaran.
\end{abstract}

How to Cite: Iskandar, R. (2020). Penggunaan Grup WhatsApp Sebagai Media Pembelajaran DTA At-Tawakal Kota Bandung. Comm-Edu (Community Education Journal) 3 (1), 97-101.

\section{PENDAHULUAN}

Diniyah takmiliyyah awaliyyah (DTA) adalah suatu pendidikan keagamaan islam nonformal yang menyelenggarakan pendidikan agama islam sebagai pelengkap bagi peserta didik yang menyelenggarakan pendidikan agama islam tingkat dasar.

Pembelajaran di DTA tidak lepas dengan pemberian materi dengan menggunakan media pembelajaran yang seadanya dan biasa dilakukan, seperti media pembelajaran dengan menggunakan white board, buku, OHP dan sebagainya dalam proses pembelajaran. Dalam era globalisasi yang semakin maju dan berkembang teknologi seperti sekarang ini, tutor 
mempunyai peran dan pastisipasi dalam pengembangan media pembelajaran sehingga akan terjadi adanya suatu perubahan dalam proses pembelajaran dan penyampaian materi pembelajaran. Tingginya tuntutan hasil dalam proses pembelajaran menyebabkan semakin banyak tutor dituntut oleh orang tua agar anaknya mampu mendapatkan hasil yang terbaik dari proses pembelajaran yang dilakukan, walaupun sesungguhnya kebutuhan tersebut seharusnya dipenuhi oleh orang tuanya di rumah.

Menurut Trianto (2010: 17) menyebutkan bahwa: "Pembelajaran merupakan aspek kegiatan manusia yang kompleks, yang tidak sepenuhnya dapat dijelaskan. Pembelajaran dapat diartikan sebagai produk interaksi berkelanjutan antara pengembangan dan pengalaman hidup. Pembelajaran dalam makna kompleks adalah usaha sadar dari seorang guru untuk membelajarkan siswanya (mengarahkan interaksi siswa dengan sumber belajar lainnya) dalam rangka mencapai tujuan yang diharapkan". Sedangkan menurut Aqib (2013: 66) menyatakan bahwa proses pembelajaran adalah upaya secara sistematis yang dilakukan guru untuk mewujudkan proses pembelajaran berjalan secara efektif dan efisien yang dimulai dari perencanaan, pelaksanaan dan evaluasi.

Atas dasar teori pembelajaran menurut para ahli diatas, maka dapat disimpulkan bahwa pembelajaran adalah suatu proses interaksi antara peserta didik dengan tutor dan lingkungannya juga beserta seluruh sumber belajar yang lainnya yang menjadi sarana belajar guna mencapai tujuan yang diinginkan dalam rangka untuk perubahan akan sikap serta pola pikir peserta didik.

Proses pembelajaran dirasa akan menambah hasil tujuan dalam pembelajaran, jika proses pembelajaran tersebut ditunjang dengan adanya media pembelajaran. Media pembelajaran adalah alat bantu proses pembelajaran yang digunakan sebagai perangsang pikiran, perasaan, perhatian dan kemampuan atau keterampilan peserta didik. Media pembelajaran ini diadakan sebagai alat bantu dalam proses pembelajaran. Pengembangan media dalam proses pembelajaran sangat dibutuhkan sebagai penyampaian materi yang baik.

\section{METODE}

Metode yang digunakan dalam penelitian ini merupakan metode deskriptif dengan pendekatan kualitatif. Menurut Sugiono (2005) menyatakan bahwa metode deskriptif adalah suatu metode yang dapat memberikan deskripsi lengkap mengenai hasil penelitian tetapi tidak digunakan untuk kesimpulan yang lebih luas. Sedangkan menurut Nazir (1988), metode deskriptif merupakan suatu metode dalam meneliti status sekelompok manusia, suatu obyek, suatu set kondisi, suatu sistem pemikiran ataupun suatu kilas peristiwa pda amasa sekarang. Adapun instrumen penelitian ini adalah menggunakan instrumen wawancara, observasi dan studi dokumentasi. Responden pada penelitian ini sebanyak 2 orang pendidik dan 5 orang peserta didik. Penelitian ini dilakukan di DTA At-Tawakal Jalan Laswi (Lingkar Selatan) No. 132 Kelurahan Samoja Kecamatan Batununggal Kota Bandung. Teknik analisi data Subyek dalam penelitian ini adalah tutor dan peserta didik DTA At-Tawakal. Menurut Moleong (2004: 280281) teknik analisis data adalah proses mengorganisasikan dan mengurutkan data ke dalam pola, kategori dan satuan uraian dasar sehingga dapat ditemukan tema dan tempat dirumuskan hipotesis kerja seperti yang disarankan oleh data. Teknik analisis data dalam penelitian ini dilakukan dengan cara sebagai berikut: pengumpulan data, reduksi data, display data, dan penarikan kesimpulan. 


\section{HASIL DAN PEMBAHASAN}

\section{Hasil}

Pelaksanaan penggunaan grup WhatsApp sebagai media pembelajaran peserta didik DTA AtTawakal Kota Bandung dalam penelitian ini berjalan cukup baik dan terencana. Dalam pelaksanaanya grup WhatsApp tersebut dijadikan sebagai media pembelajaran bagi peserta didik dengan cara para tutor mengshare materi pembelajaran yang disampaikan melalui grup tersebut agar peserta didik yang berhalangan untuk hadir masih mampu untuk melakukan pembelajaran di rumah. Latar belakang dari penyelenggaraan penelitian ini adalah dengan melihat pada situasi dan kondisi yang terjadi di DTA At-Tawakal telihat bahwa diera globalisasi saat ini peserta didik dan tutor tidak terlepas dari penggunaan gadget sehingga terpikir bahwa gadget mampu dijadikan sebagai media pembelajaran tutor terhadap oleh peserta didik.

Berdasarkan hasil penelitian di lapangan pelaksanaan penggunaan grup WhatsApp sebagai media pembelajaran terhadap peserta didik DTA At-Tawakal di Kota Bandung dibagi menjadi dua tahap yaitu: tahap pelaksanaan yang dilakukan dengan cara mengidentifikasi, sosialisasi program, rapat koordinasi dan penetapan program yang meliputi: merumuskan program, menetapkan tujuan program, menyiapkan materi pembelajaran, rekruitmen tutor dan peserta didik pendidik. Pelaksanaan yang lebih diperhatikan pada teknisnya meliputi: sarana dan prasarana, tutor dan materi pembelajaran. Monitoring yang dilakukan untuk mengukur keberhasilan program yang dilaksanakan. Monitoring pada penggunaan grup WhatsApp sebagai media pembelajaran terhadap peserta didik DTA At-Tawakal di Kota Bandung dilakukan oleh ketua grup WhatsApp tersebut. Aspek yang dimonitoring mencakup hal-hal sebagai berikut: pelaksanaan dan pendampingan.

Hasil pelaksanaan penelitian ini dalam penggunaan grup WhatsApp sebagai media pembelajaran terhadap peserta didik DTA At-Tawakal di Kota Bandung tutor dan peserta didik mampu saling terbantu dengan adanya media pembelajaran tersebut.

Evaluasi pelaksanaan penelitian ini dalam penggunaan grup WhatsApp sebagai media pembelajaran terhadap peserta didik DTA At-Tawakal di Kota Bandung adalah memperbaiki kekurangan dan hambatan yang ada.

\section{Pembahasan}

Hasil Penelitian yang peneliti dapatkan melalui wawancara, observasi dan dokumentasi mengenai pelaksanaan penggunaan grup WhatsApp sebagai media pembelajaran terhadap peserta didik DTA At-Tawakal di Kota Bandung melalui dua tahap. Tahap pertaman adalah pelaksanaan yang dilakukan yaitu dengan mengidentifikasi situasi yang ada, mensosialisasikan program, rapat koordinasi dan penentuan program. Pelaksanaan program mengidentifikasi situasi yang dirasakan oleh tutor dan peserta didik, melakukan sosialisasi kepada tutor dan peserta didik mengenai penggunaan grup WhatsApp sebagai media pembelajaran, melakukan koordinasi kepada para tutor sebagai pengguna grup WhatsApp tersebut dan menentukan program apa saja yang mampu dishare pada peserta didik melalui grup tersebut. Monitoring dalam berbagai kegiatan program perlu dilakukan untuk mengukur keberhasilan program yang dilaksanakan. Monitoring pada kegiatan penggunaan grup WhatsApp sebagai media pembelajaran di DTA At-Tawakal Kota Bandung dilakukan oleh ketua grup WhatsApp tersebut. 
Hasil penelitian ternyata dirasa sangat bermanfaat bagi tutor dan peserta didik dalam penggunaan grup WhatsApp sebagai media pembelajaran, hal ini dibuktikan dengan hasil evaluasi yang dilakukan oleh ketua grup tersebut tutor dan peserta didik mampu mengatasi berbagai kekurangan dan hambatan yang terjadi dalam proses grup WhatsApp sebagai media pembelajaran. Schramm (1977) dalam Rudi dan Cepi (2008: 6) menjelaskan media pembelajaran adalah teknologi pembawa pesan yang dapat dimanfaatkan untuk keperluan pembelajaran.

Evaluasi merupakan proses yang dilakukan untuk mengetahui sejauh mana suatu program tersebut dapat dilaksanakan dan sejauh mana tujuan program tersebut dapat tercapai. Arikunto (2008: 3) bahwa mengukur adalah membandingkan sesuatu dengan satu ukuran (bersifat kuantitatif), menilai adalah mengambil suatu keputusan terhadap sesuatu dengan ukuran baik buru (bersifat kualitatif) dan evaluasi meliputi kedua langkah tersebut. Pendapat lain mengenai evaluasi disampaikan kembali oleh Arikunto dan Cepi (2009: 2), bahwa evaluasi adalah kegiatan untuk mengumpulkan informasi tentang bekerjanya sesuatu, yang selanjutnya informasi tersebut digunakan untuk menetukan alternative yang tepat dalam mengambil sebuah keputusan. Evaluasi diarahkan untuk mengetahui keberhasilan tujuan program, tingkat keberhasilan peserta, hambatan-hambatan yang ada selama program, dan memperoleh informasi yang tepat sebagai acuan dalam membuat keputusan tentang program. Dalam hal ini pelaksanaan grup WhatsApp sebagai media pembelajaran menjadikan program mampu berjalan dengan baik dan tujuan mampu tercapai dengan cukup baik dalam peningkatan pembelajaran. Pelaksanaan program penggunaan grup WhatsApp sebagai media pembelajaran merupakan upaya penguatan dan pengembangan dalam proses pembelajaran bagi tutor dan peserta didik. Tujuan diadakanya penggunaan grup WhatsApp sebagai media pembelajaran yaitu: 1) untuk memperluas pengetahuan tutor dan peserta didik mengenai suatu penggunaan aplikasi sebagai media pembelajaran, 2) melalui pelaksanaan program penggunaan grup WhatsApp sebagai media pembelajaran ini diharapkan tutor dan peserta didik terbantu dalam proses penyampaian materi pembelajaran, 3) melalui pelaksanaan program penggunaan grup WhatsApp sebagai media pembelajaran ini diharapkan tutor dan peserta didik mampu mengaplikasikan dan menjadikan aplikasi ini sebagai salah media pembelajaran yang digunakan untuk pengembangan dalam proses pembelajaran.

Hasil pelaksanaan program penggunaan grup WhatsApp tersebut terlihat bahwa penggunaan grup WhatApp sebagai media pembelajaran mampu membantu tutor dan peserta didik dalam mempermudah penyampaian materi pembelajaran.

Evaluasi yang dilakukan dapat dilihat dari perubahan tutor dan peserta didik yang merasa sedikit terbantu dalam penyampian materi pembelajaran. Peserta didik sebelum diadakanya grup WhatsApp sebagai media pembelajaran merupakan peserta didik yang acuh jika materi pembelajaran tersebut tertinggal karena malas untuk menulis materi yang tertinggal. Berdasarkan hasil evaluasi yang dilakukan, dengan adanya penggunaan grup WhatsApp sebagai media pembelajaran maka tutor dan khususnya peserta didik mampu mengatasi kekurangan dan hambatan yang terjadi pada proses pembelajaran sebelum adanya penggunaan grup tersebut. Peserta didik mampu menggunakan grup tersebut sebagai media pembelajaran jika berhalangan hadir dan tetap memiliki materi pembelajaran tanpa harus tertinggal dan tutor mampu mengshare materi pembelajaran di grup tersebut untuk peserta yang tidak dapat hadir pada proses pembelajaran. 


\section{KESIMPULAN}

Berdasarkan hasil penelitian mengenai pelaksanaan grup WhatsApp sebagai media pembelajaran DTA At-Tawakal Kota Bandung maka peneliti dapat menarik kesimpulan sebagai berikut, penggunaan grup WhatsApp sebagai media pembelajaran dirasa cukup membantu tutor dan peserta didik dalam proses pembelajaran sebagai pengembangan media pembelajaran. Peserta didik yang tertinggal materi pembelajaran karena tidak halangan tidak bisa hadir kini tidak perlu untuk meminta materi pada temanya karena tutor mampu mengshare materi pembelajaran yang tertinggal itu pada grup tersebut.

\section{DAFTAR PUSTAKA}

Arikunto, S. (2008). Dasar-dasar Evaluasi Pendidikan. Jakarta Bumi Aksara.

Arikunto \& Cepi, S.A.J. (2009). Evaluasi Program Pendidikan. Jakarta: Bumi Aksara.

Aqib, Zainal. 2013. Model-model, Media, dan Strategi Pembelajaran Kontekstual (Inovatif). Bandung: Yrama Widya.

Moleong, Lexy, J. (2004). Metodelogi Penelitian Kualitatif. Bandung: Remaja Rosdakarya. Nazir, M. (1988). Metode Penelitian. Ghalia Indonesia: Jakarta.

Rudi, S., \& Cepi, R. (2008). Media Pembelajaran. Bandung: Jurusan Kurtekpend FIP UPI. Sugiyono. (2005). Metode Penelitian Administrasi. Bandung: Alfabeta.

Trianto, 2010. Model Pembelajaran Terpadu.Jakarta: Bumi Aksara. 